DOI: $10.17805 /$ zpu.2018.3.6

\title{
Самотворчество и принципы работы с представлениями в школе Эпиктета
}

\author{
A. А. ГОРЕЛОВ \\ ИНСТИТУТ ФИЛОСОФИИ РАН
}

В статье обсуждается значение работы с представлениями в школе римского стоика Эпиктета для развития человека. В первой части статьи анализируется понятие самотворчества в его соотношении с понятием творчества. Анализируются три значения понятия самотворчества: бессознательное воздействие творчества на самого творца, сознательное воздействие с помощью культуры на собственное бытие автора и сознательное воздействие на самого человека-творца как самоцель. Управление представлениями рассматривается как важный этап самотворчества, ведущий в дальнейшем к изменению поведения и образа жизни.

Рассматриваются постигающие и непостигающие, истинные и ложные представления; дилемма «мое - чужое», которая приобретает у Эпиктета основополагающее значение; понятие свободы воли, которое распространяется римским стоиком только на то, что является для человека своим. Анализируются принципы, используемые Эпиктетом: 1) «уясняй» представления в соответствии с велениями бога, поведением великих философов, интересами целого и собственными соответствующими природе целями самосовершенствования; 2) «свое блюди всячески, чужого не домогайся»; 3) отстраняйся от всего, что не зависит от твоей свободы воли. Проводятся аналогии между буддистским освобождением от желаний и Эпиктетовым освобождением от чрезмерной привязанности к внешней реальности; свободой выбора, о которой пишет Эпиктет, и экзистенциалистической концепцией этического выбора.

Несмотря на то что стоицизм не является сейчас модным философским направлением, принципы, сформулированные Эпиктетом, воспроизводятся в современной философской и психологической литературе. Например, принцип непривязанности к внешней материальной действительности, принцип гиперстимуляции и гипостимуляции, используемые для достижения измененных состояний сознания, и тому подобные восходят к учению Эпиктета. В наше время взгляды стоиков, и в частности Эпиктета, становятся столь же актуальными, как они были в Античности.

Ключевые слова: самотворчество; Эпиктет; Сократ; Диоген; стоики; постигающее представление; мое - чужое; безразличное; свобода воли; философия творчества 


\section{ВВЕАЕНИЕ}

Количество информации растет по экспоненте, а современные средства связи делают ее свободно циркулирующей по всему земному шару во всем ее многообразии, когда на второй план уходит различение истины и лжи, появляется новое слово «постправда» и модным становится выражение «фейковые новости». Человек становится совершенно беззащитным перед этим потоком, что негативно действует на его здоровье.

Конечно, СМИ отражают (с громадными преувеличениями и искажениями) реальную жизнь с ее конкуренцией, борьбой всех против всех, индивидуализмом, распадом семьи, трудовых коллективов, неформальных объединений граждан (но не преступных группировок) и недоверчивым отношением к окружающим (кое-где в сельской местности входные двери в дом и квартиру еще не закрывают, а в мегаполисах их уже не открывают чужим), отсутствием веры как в Бога, так и в светлое будущее. Аанную реальность отражают наши представления, и она не изменится сама по себе, если мы будем безучастно пропускать информацию через себя.

Необходимо критическое отношение к получаемой информации и нашим собственным представлениям. В связи с этим особую актуальность приобретают слова Эпиктета: «Так посвяти же все свои усилия представлениям, проведи ночи в трудах над ними. Не незначительно ведь оберегаемое: это совесть, честность, стойкость, неподверженность страстям, неподвластность печалям, неподвластность страхам, невозмутимость, словом, свобода» (Беседы Эпиктета, 1997: 234).

\section{ТВОРЧЕСТВО И САМОТВОРЧЕСТВО}

Самотворчество понимается как особая разновидность творчества, относящегося к самому творцу, который пытается изменить себя в соответствии со своими представлениями о том, каким он должен быть.

Можно выделить три значения понятия самотворчества. Во-первых, дюбой вид творчества оказывает влияние на самого автора, хочет он того, думает над этим или нет. В философии творчества обсуждается вопрос о том, как возможно создание качественно нового, не бывшего прежде. Ученые изучают образование новых нейронных цепей в мозгу человека в результате сознательного или бессознательного перебора различных вариантов решения возникающих проблем. Чтобы создать новое, надо измениться самому, стать таким, каким не был ранее. В определенном смысле это и будет самотворчество. Творчество служит «высвобождению скрытого» (Г. Марсель) в мире и в самом человеке. Изменение личности, делающее возможным создание нового, есть часть творческого процесса.

Стало быть, под самотворчеством можно понимать бессознательное воздействие творчества на самого творца, даже если он этого не замечает. Так как создание нового предполагает открытие нового в самом себе, творение произведений культуры неразрывно связано с самотворчеством. Но человек способен осознать то, что его созидательная работа оказывает воздействие на него самого, обстоятельства его жизни и окружающую его среду, и ценность конечного продукта может в той или иной степени определяться получаемыми практическими результатами. Это вариант осуществления желания самосозидания посредством творчества культуры.

Итак, вторым значением понятия самотворчества будет сознательное воздействие с помощью творчества культуры на собственное бытие. Такой вариант характерен для магии и науки (особенно для современной системы «наука - техника»). 
Наконец, третье значение понятия самотворчества представляет собой сознательное, как и в предыдущем случае, воздействие на самого себя, но как самоцель без создания произведений культуры. В этом случае самотворчество становится прямой и главной целью. Такой путь характерен для мистики и религии. Как писал Н. А. Бердяев, «святому может быть присуща гениальность в самотворчестве, в превращении себя в совершенную просиянную тварь, хотя никаких продуктов он может и не создавать» (Бердяев, 1993: 120).

Самотворчество образно определяется как превращение себя в произведение искусства. Творить - новую ли плоть или духовные ценности - значит вырваться на волю из плена своего тела. Когда человек начинает творить произведения культуры или самого себя, он раскрывает и трансцендентирует себя. Иногда для одного и того же индивида в определенный период жизни основным является создание произведений культуры, а в другой - самотворчество, и наоборот. Например, «...вся жизнь $\Lambda$. Толстого была мучительным переходом от творчества совершенных художественных произведений к творчеству совершенной жизни» (Бердяев, 1989: 438).

Если человек - единственное существо, сознающее свою смертность, то он же и выработал способ достижения бессмертия - творчество. Если оно гармонизирует внутреннюю жизнь человека и отвлекает его от плохих мыслей и поступков, то тогда оно - признак душевного здоровья. Если творчество исцеляет, то самотворчество в единстве созидания культуры и самого творца исцеляет еще в большей степени, так как сознательно стремится к самосовершенствованию личности.

Отметим различие между понятиями самотворчества и творчества человека. Самотворчество, как любой творческий процесс, представляет собой создание нового, в данном случае нового человека взамен старого, «ветхого», предполагая пользу от этого для данного индивида, человечества и эволюции (религиозный эквивалент: соединение с Богом и выполнение Его велений). Задача создания нового человека ставилась и в философской, и в религиозной, и в идеологической литературе (в $\mathrm{XX}$ в. она была поставлена в СССР в рамках коммунистической идеологии). Но когда мы говорим о самотворчестве, то имеем в виду не воздействие одних людей на других, а воздействие индивида на самого себя.

Самотворчество соотносится, а в определенном смысле противостоит созданию произведений культуры. Это два различных и во многом противоположных способа деятельности. В первом случае создаются священные книги, философские трактаты, художественные сочинения, научные открытия, картины и т. А., во втором произведением является сам человек как духовно-телесное существо. Аевизом здесь становится афоризм: «Жить - значит сделать художественное произведение из самого себя».

Оба пути тесно связаны друг с другом в целостном развитии индивида, хотя если говорить о конкретном авторе, то он может выбрать какой-либо один из них или переходить от одного к другому. Так, люди, считающиеся святыми, не очень-то заботились о создании произведений культуры, но творили образцы поведения. Например, в русской культуре этим путем шел великий религиозный деятель средневековой Руси Сергий Радонежский. Аругие, наоборот, ценны именно своими духовными творениями. Имеет место и промежуточный путь, когда человек, создавший гениальное произведения культуры, сознательно становится на путь творения совершенной жизни (в русской культуре образцом этого служит $\Lambda$. Толстой). Можно одновременно двигаться и в теоретическом, и в практическом направлении. В философии это полу- 
чило название «пифагорейского образа жизни», когда мудрец в процессе культурной деятельности достигает одновременно практических результатов (помимо Пифагора ярким примером здесь выступает Сократ).

Самотворчество требует разработки определенных способов и методов, которые могут действовать как на сознательном, так и на подсознательном уровне. Сознательный способ самотворчества включает в себя несколько этапов, один из которых воздействие на представления.

\section{РОАЬ ПРЕАСТАВАЕНИЙ В САМОТВОРЧЕСТВЕ}

Понятие представления (греч. «фантазия») играет важную роль в истории философии начиная от ее истоков. В самом широком смысле представлением можно назвать весь материал, являющийся в сознании. Эпиктет относит сюда «мнения, желания и стремления, влечения и уклонения» (Флавий Арриан, 2007: 626) как внутренние продукты сознания. Это промежуточное звено между ощущением и восприятием, с одной стороны, и объективным, обобщающим знанием как высшим плодом человеческого разума - с другой.

Ауховную составляющую человека ставят на высшее место, потому что именно дух является управляющей подсистемой человека, хотя эволюционно первичным считается тело. Нервная система, а затем у более высокоорганизованных живых организмов мозг сформировались как органы, которые руководят деятельностью всех других частей тела. «Но дух господствует над плотью и над всем, что принадлежит телу» (Эпиктет, 1995а: 252). Но развитие может идти и в противоположную сторону, когда изменения тела влияют на нашу душу, а затем последняя начинает определять представления индивида в соответствие с формулой «бытие определяет сознание». Такая ситуация возможна и основывается на первичности телесных импульсов с последующим изменением сознания. При этом не человек управляет собой с помощью разума, а им управляют ранее организованные подсистемы. Возникающие представления в качестве завершения и последней стадии цепочки будут, таким образом, инволюционным результатом отказа разума от своей руководящей роли.

Самотворчество, напротив, предполагает сознательное регулирование представлений. Ум человека осуществляет управление состояниями сознания. Итак, исходная точка самотворчества - представления. В силу взаимосвязи в человеке тела, души и ума изменение сознания действует на душу и тело, в результате чего созидается личность и ее бытие. Это можно представить в виде развернутой трехэтапной схемы: 1) ум (состояния сознания, представления, т. е. мысли, слова и общение в позитивном духовном направлении вплоть до непривязанности к материальным объектам реального мира); 2) душа (очищение от негативных страстей и достижение благострастия и отсутствия желаний); 3) тело (исцеление, здоровье и гармония составных частей организма).

Итак, изменение состояния сознания, направляемое разумом, ведет к бесстрастию по отношению к негативным страстям и благострастию по отношению к лучшим движениям души и далее к телесному здоровью и гармонии ума, души и тела. Рассматривая сознательную сферу человека, мы будем использовать принятое в современной психологической литературе понятие состояния сознания и аналогичное более традиционное понятие представления. Последнее было одним из основных в стоической философии, особенно у Эпиктета, который под представлениями понимал образы и мысли, входящие и присутствующие в сознании человека. 
Эпиктет часто пользовался аналогией между жизнью и театром. Он считал, что важно не то, какую роль ты играешь и кем ты являешься на сцене, а то, как ты играешь эту роль - хорошо или плохо. «Если ты возьмешься за роль, превышающую твои силы, и в ней себя опозоришь, то потеряешь и ту, которую смог исполнить» (Флавий Арриан, 2007: 528). Главное, хорошо сыграть данную тебе богом роль. Сравнение жизни с театром встречается у Эпиктета неоднократно. Перенеся данную аналогию на понятие представления и учитывая, как оно понимается в современной общекультурной жизни, можно сказать, что представление по Эпиктету - это как бы «спектакль» в душе самого человека и он зависит от него самого и от того, какую цель он преследует. Каждый индивид - автор собственных представлений, которые хотя и приходят к нему спонтанно, из толщи его собственного бессознательного (как и все творческие продукты), но благодаря разуму либо принимаются ( «оправдываются»), либо отвергаются (в этом основная функция разума). Создавая свои «спектакли», творец создает себя и свое имя. Насколько он волен в своем произведении, настолько он обладает свободой воли в управлении собственным представлением.

Эпиктет не пользовался понятиями «состояние сознания», «поле сознания», «изменение состояния сознания», «расширение сознания» и другими, которые появились относительно недавно в психологии, когда выяснилось, что элементарной единицей душевной жизни является душевное состояние человека целиком, а не отдельные представления, которые приходят в голову индивида. Но для наших целей это различие не является принципиальным, поэтому мы будем чаще использовать понятие «представление», основополагающее у Эпиктета.

Представления доставляют нам различные отрасли культуры - искусство, философия, религия, наука, идеология - и многообразные жизненные ситуации, в которые мы вовлечены. Если мы хотим изменить себя и окружающую среду, то должны контролировать представления, «мужественно противостоять» (Влахос) негативным помыслам и заменять их на другие, позитивные, памятуя о том, что «все радости и несчастья людей созданы их собственными мыслями» (Митрополит Иерофей, 2013: 235).

Изменения состояний сознания определяются двумя факторами - знанием и волей. Первый из них обеспечивается культурой, второй - характером индивида. На достижение преобразования представлений в желательном направлении ориентированы различные социальные образования, в том числе такие знаменитые, как философская школа «нравственной гимнастики» Эпиктета, о которой речь идет ниже, а также множество различных социальных объединений - от религиозных конфессий до бытовых групп по интересам, например обществ анонимных алкоголиков.

Как творчество в целом может быть позитивным (эволюционным) и негативным (инволюционным), так и самотворчество может быть позитивным и негативным - позитивным, если оно делает человека более одухотворенным, здоровым, радостным, и негативным, если человек заболевает, деградирует, разрушается. Соответственно, представления могут быть позитивными (эволюционными) и негативными (инволюционными). Нас будут интересовать именно позитивные изменения как в бытовом (например, отказ от курения), так и в философском и религиозном смысле (например, самосовершенствование личности).

Если состояние сознания устраивает нас, являясь позитивным, нам нет необходимости воздействовать на него с целью трансформации. Но когда приходящие представления нежелательны, необходимо предпринимать усилия, чтобы изменить либо данное состояние сознания, либо отношение к нему. Последний способ реагирования 
на нежелательные представления предлагает философия. Ничего не меняя в пришедшем представлении, надо так в своем сознании переинтерпретировать его, чтобы оно из негативного превратилось в позитивное.

Эта проблема всегда были актуальна из-за особенностей человеческой природы, которые влияют на приходящие к нам представления. Мы больше помним об обидах, нанесенных нам, чем о наносимых нами другим людям (следствие эгоизма). Именно поэтому священник перед началом исповеди напоминает верующим: сообщайте о своих грехах, а не о том, какие вы хорошие и что плохого сделали вам. Исповедь есть форма противодействия эгоизму, а не поощрения его. В силу отмеченной выше особенности нам и в представлениях чаще являются неприятности, причиненные нам Аругими, а не причиняемые нами, и встает проблема переориентации этих представлений в плане перехода от состояния переживания из-за того, что обидели нас, в исповедь о своих грехах. К тому же человеку большее удовольствие предоставляет «перемывание косточек» другим, чем воспоминание о собственных промахах и ошибках. Это принципиальное следствие эгоизма накладывается на современные тенденции развития общества, способствующие ухудшению данной ситуации.

\section{МЕТОАЫ РАБОТЫ С ПРЕДСТАВАЕНИЯМИ В ШКОАЕ ЭПИКТЕТА}

В различных отраслях культуры, используемых для самотворчества, - философии, религии, науке, искусстве - есть нечто общее и в каждой из них присутствует своя специфика. Мы обратимся к примеру философии, рассматриваемой как духовное упражнение (Адо, 2005), и прежде всего античного стоицизма, практической вершиной которого стало учение Эпиктета (ок. 50 - 130-140 гг.). Предшественниками стоиков были киники, которые стремились ограничить телесную составляющую человека, чтобы она не мешала развитию духовно-нравственных потенций индивида. Стоики больше внимания уделяли духовно-нравственной стороне, не связывая ее жестко с телесной составляющей. И киников, и стоиков можно отнести к античному направлению философии жизни. Примыкая по своей нацеленности на решение практических задач к наиболее известным киникам (и в воззрениях, и в образе жизни Эпиктета видна большая близость его к киникам, чем у других римских стоиков), Эпиктет в то же время в теоретическом плане следовал в русле стоицизма.

Эпиктет был рабом (само имя его означало кличку «прикупленный»), и основным мотивом его деятельности стало освобождение от рабства. Ни один выдающийся греческий философ более раннего времени не был рабом и не выражал в такой резкой манере протест против рабства. «Чего не желаешь себе, не желай и другим; тебе не нравится быть рабом - не обращай других в рабство. Раз ты не можешь обойтись без услуг рабов, ты, прежде всего, сам раб, - как не уживается друг с другом добродетель и порок, так и свобода и рабство» (Эпиктет, 1995а: 256). Но Эпиктет призывал к освобождению от рабства не только в социальном смысле слова, но и в духовном. «Кто свободен телом и не свободен душою, тот раб и, в свою очередь, кто не свободен телесно, но свободен духовно - свободен» (там же: 252). Свободу человек может получить только самостоятельно, собственным усилием. «Если хочешь быть свободным, добудь сам себе свободу. Свободным же ты будешь тогда, когда отрешишься от своих страстей» (там же: 257). Ауховную свободу можно обрести в процессе самотворчества.

Творческое начало играло основополагающую роль в учении стоиков. Вся жизнь, по их представлениям, основывается на взаимосвязи бескачественной инертной мате- 
рии и пронизывающей ее творческой силы. Последняя также называется «творческим огнем», логосом, богом, Зевсом, роком. Отсюда следует то большое значение, которые стоики придают самотворчеству, учитывая, что человек рассматривается ими как микрокосм по отношению к макрокосму - вселенной.

Эпиктет избрал философский путь освобождения от рабства, и методом его стало управление представлениями. Сделать человека добродетельным и счастливым (а счастье - следствие добродетельной жизни) - единственная цель философии, по Эпиктету, для которого философия - наука или искусство жизни. Заниматься философией значит воздействовать на окружающих, и философ есть воспитатель человечества (Маковельский, 1912: 6). «Если хочешь жить спокойно и весело, старайся вести знакомство только с хорошими людьми. Хорошими же будут они для тебя тогда, когда ты займешься перевоспитанием тех из них, кто станет охотно слушать тебя» (Эпиктет, 1995а: 253).

Говоря о ступенях философского обучения, Эпиктет утверждал, что начало философии - осознание своего незнания, собственной слабости и бессилия относительно самого важного в жизни - того, как необходимо поступать. «Если хочешь быть хорошим, сперва проникнись убеждением, что ты дурной» (Маковельский, 1912: 6), и что ум твой - ложный. Посему прежде всего нужно «сойти с ума», т. е. отбросить мнимое знание (иначе учеба не принесет желаемых результатов). Аечение души и тела начинается с отказа от общепринятых догматов и овладения новыми, правильными взглядами, которые являются парадоксальными с точки зрения обывательского рассудка, но не паралогичными. Начинающий философ как бы оказывается вне себя, теряет устойчивость и понимание того, что он хочет. «Новое воззрение на мир будет усвоено внутренним образом, когда оно станет чувством и волей» (там же: 7).

Человеку дан природой разум именно для того, чтобы пользоваться, как должно, представлениями. «Поэтому дело философа, важнейшее и первое, - одобрять и различать представления и не принимать ни одного неодобренным» (Беседы Эпиктета, 1997: 74). «Философия не обещает дать человеку ничего того, что относится к внешнему миру» (там же: 66), но способна обеспечивать его спокойствие посредством, в частности, работы с представлениями.

Эпиктет тем выгоднее отличается от других римских стоиков, что его жизнь полностью соответствовала тому, что он проповедовал. Будучи отпущен на свободу, он вел спартанский образ жизни. Все его имущество состояло из соломенной подстилки, циновки, деревянной скамьи и глиняной лампы. Вся его деятельность была направлена на практическое осуществление идеалов стоицизма. С этой целью Эпиктет основал школу нравственного самосовершенствования, которая привлекала к себе людей разных сословий - от рабов и бедняков до аристократов. Открыл он ее в Никополе после изгнания из Рима в 94 г., а затем, после разрешения вернуться в Рим, перенес ее в Вечный город.

Свою философско-воспитательную школу Эпиктет называл лечебницей. Он ждал к себе не тех учеников, которые приходят узнать что-либо, в том числе о своей болезни, а таких, которые хотят выздороветь. О том, что это не всегда получалось так, видно из его горестного восклицания: «Аа кто приходит в школу, кто, для того, чтобы излечиться?» (там же: 140). Сама болезнь - это проверка занимающихся философией. Если ученик вылечился, значит, философия ему помогла и цель достигнута.

О школе Эпиктета мы в основном можем судить по книге «Беседы Эпиктета», составленной из записанных его учеником Аррианом лекций учителя. Этот яркий, эмо- 
ционально насыщенный текст дает представление о цели обучения и тех трудностях, которые пытается преодолеть ее основатель. К тому, что изучается в его школе, надо относиться как к лекарству, которое нужно правильно принимать. «И вы еще говорите: "Правила бесполезны". Аля кого? Аля тех, кто пользуется ими не как следует. Ведь глазные мази не бесполезны для тех, кто мажет их когда следует и как следует, мягчительные средства не бесполезны, гири не бесполезны» (там же: 140). Обращаясь к «Беседам Эпиктета», мы как бы входим в его школу, и к этому следует относиться со всей серьезностью.

Аля того чтобы обучение в школе Эпиктета принесло пользу, необходимо подготовиться. Это первый, предварительный этап обучения. «И вы тоже, люди... приведите в покой мысль, приходите в школу с мыслью ничем не отвлекаемой, и вы узнаете, какую силу имеет разум» (там же: 141). Не надо надеяться на скорый эффект. Необходимо запастись терпением. И не следует переживать из-за того, что мы никогда не приблизимся к идеалу. Римский стоик обращается к двум своим греческим предшественникам, служившим для него образцом поведения, и советует почаще о них вспоминать, - к Сократу и Аиогену. «Эпиктет лучше Сократа не будет. Но если не хуже, этого мне достаточно» (там же: 14). Если мы в наших условиях хоть немножко приблизимся к Сократу, и то хорошо. Главное - постоянные духовные упражнения и усилия Аля достижения практического результата.

Эпиктет - философ не на словах, а на деле, и подчеркивает значение практики, обращаясь к примерам других специалистов. «Строитель не приходит и говорит: “Послушайте мои рассуждения о строительном искусстве”, но, нанявшись на постройку дома и построив его, показывает, что владеет этим искусством» (там же: 184). Это же относится и к ученикам школы «нравственной гимнастики». «Разве не должны они вернуться к себе терпимыми, способными к содействию, неподверженными страстям, невозмутимыми, имея некое такое средство для жизни, благодаря которому смогут правильно переносить все случающееся и благодаря этому украшать себя?» (там же: 185).

Цель учебы у Эпиктета - стать неподвластным препятствиям и печалям; невозмутимым и неподверженным страстям, твердым и непоколебимым. Эпиктет не совершил таких громких деяний, как Сократ и Аиоген, но он разработал методы работы над собой, которыми могли воспользоваться все ученики, и умел убеждать желающих стать лучше. Чувствуется, как Эпиктет «заряжает» своих слушателей, дает, говоря языком современных психотерапевтов, «установку на добро». Не удивительно, что в его школу приходило множество людей разных сословий. Бывший раб Эпиктет превзошел своим духом не только римских граждан и элиту общества, но и императора Марка Аврелия.

Наибольшее значение имеют не столько мысли Эпиктета о том, каким должен быть человек, сколько его практические методы достижения идеала поведения. И здесь отправной точкой служит обладание способностью «уяснять» смысл всего происходящего в мире и целого как такового в его отношении к индивиду; постичь критерий того, что по природе, а что нет, и важность деятельности в соответствии с природой вещей. Напомним, что еще Аристотель, который, в свою очередь, основывался на взглядах Сократа и Платона, писал о том, что для правильной жизни необходимо понимающее знание. Следствием развития способности «уяснять» является «чувство благодарности» к целому и «восхваления промысла» за все происходящее. «Правильно быть здоровым - благо, неправильно - зло. - Так что и от болезни можно получить пользу? - Ради бога, да разве от смерти нельзя?» (там же: 183). 
Уверенность в справедливом божественном порядке доставляет человеку «высшее счастье и необычайную стойкость души» (Ажемс, 1992: 296). Вот для чего нужна вера во всеблагого бога и в порядок целого, который призван поддерживать каждый индивид. Ощущение единства, всесвязанности мира, тождество с ним и растворение в нем приносят человеку неизъяснимое блаженство и сияющую радость. Полис как главная социальная единица общественного устройства превратился у стоиков в космополис, называемый также мирозданием (эта концепция заимствована стоиками у киников). Аействовать согласно природе, к чему призывали стоики, и означает поступать согласно целому, понимаемому и как бог, и как космополис.

Аобродетельный человек должен думать о том, как ему «быть довольным божественным управлением» (Беседы Эпиктета, 1997: 62). Приоритет целого позволяет, по Эпиктету, прийти к правильному пониманию соотношения добра и зла. Мы должны принять зло по отношению к нам как частичке целого, ибо это зло - средство для достижения более высокого блага, блага целого. Негативные представления нужны как средство Аля нашего совершенствования или для блага целого, которому мы должны покоряться.

Эпиктет использует понятие «постигающего представления» как такого, которое схватывает реально существующее в соответствии с его внутренней сутью. Такие представления считались стоиками критерием истины. Противоположное - «непостигающее представление» - называлось ими ложным, от которого надо отказываться. Например, «не бедность следует отвергать, но мнение о ней, и вот тогда мы будем благоденствовать» (там же: 181). Это можно назвать позитивной переоценкой представлений. Постигающее представление можно сопоставить с понятием трезвения в христианстве и с понятием осознания, как оно используется в современной психологии. Подчеркивая важность правильного понимания представлений, Эпиктет восклицал: «Аа какая буря страшнее, чем вызываемая представлениями, имеющими силу и способными смести разум?» (там же: 131-132).

Исключительно важно такое методическое правило Эпиктета: не соглашаться сразу с пришедшими в голову представлениями, а сказать: “"Погоди немного, представление, дай посмотреть, кто ты и о чем, дай проверю, одобрить ли тебя” <...> Но лучше призови вместо него какое-нибудь другое, прекрасное и благородное представление, а это грязное отбрось» (там же: 131). Эпиктет неоднократно повторяет эту мысль. «...Когда представление терзает тебя (ведь это не от тебя зависит), борись с ним разумом, одолевай его, не давай ему быть в силе и уводить все дальше, рисуя в своем воображении одно за другим все что хочет и как хочет» (там же: 209). Правило осознания требует «даже во сне не упустить неисследованным какое-нибудь явившееся представление, даже при опьянении, даже когда нападет умопомрачение» (там же: 158). Сделать это можно только при постоянной тренировке. Принцип Эпиктета «следи за собой, как за злейшим врагом» предполагает и непрерывный контроль собственных представлений.

То, как «уяснение» позволяет жить без страха и печали и становиться сильнее, Эпиктет демонстрирует на примере подвигов Геракла. «А то чем, по-твоему, вышел бы Геракл, если бы не существовало такого льва, гидры, лани, вепря, всяких несправедливых и звероподобных людей, от которых он избавил и очистил землю?» (там же: 50-51). Как гласит русская пословица, «на то и щука, чтоб карась не дремал». Итак, мы можем придать каким-либо негативным представлениям позитивное значение как помогающим подготовиться к реальной борьбе с тем злом, которое предстоит победить. Трудности и враги нужны для упражнений в стойкости, закалки характера и об- 
ретения мужества, хотя задача стоиков - не искать врагов, а освободить человека от нежелательных представлений, мешающих нормально жить.

«Уяснение» позволяет принять многие негативные представления, не тратя усилий на их изменение или ликвидацию, а переосмысливая их с помощью дополнительных соображений (ту же функцию выполняет христианская максима «что Бог ни делает, все к лучшему»). «Аюдей показывают обстоятельства. Стало быть, когда тебе выпадет какое-то обстоятельство, помни, что это бог, как учитель борьбы, столкнул тебя с грубым юнцом. - Аля чего, - говорит. - Аля того, чтобы ты стал победителем на Олимпийских играх. А без пота не стать» (там же: 78). Надо принять независящие от тебя обстоятельства, которых ты не в силах изменить, и подстраивать под них свои представления. «Самая трудная и достойная победа - победа над собственным представлением, - утверждает Эпиктет. - Она дороже победы на Олимпийских играх» (там же: 131), но и труднее. «Покажите мне кого-нибудь, кто болеет, и все же счастлив, кто в опасности, и все же счастлив, кто умирает, и все же счастлив» (там же: 134). «Аушу пусть кто-нибудь из вас покажет человека, желающего... не гневаться, не завидовать, не ревновать... жаждущего стать из человека богом» (там же). Что мешает? Наша бренная оболочка, невежество, которое мы не можем или отказываемся признать.

Во всем, о чем переживаешь, виноват не кто-то другой, а собственное мнение. Измени его, и ты воспримешь ситуацию иначе. Человек ответственен только за свои представления и ни за что больше. Ими он и должен управлять. Таким образом, работа с представлениями становится важнейшим элементом самостояния человека в мире. Аобиваться хорошего мы всегда можем сами, своими силами, а другого нам не надо.

Здесь проявляется очень важная особенность творчества Эпиктета - вера во внутренние силы человека и способность совершенствования, благодаря пронизывающей его частице божественной мудрости, которая не менее важна, чем постигаемые им знания. Все внешние правила будут бесполезны, если человек не актуализирует свои внутренние позитивные творческие силы добродетели. А если ему это удастся, то все остальное теряет для него ценность. Внутреннее совершенствование человека - главная надежда Эпиктета. «Если я сам своими силами могу добиться величия духа и благородства, стану ли я добиваться с твоей помощью земли, денег и какой-то должности?» (там же: 57) - задает вопрос Эпиктет и сам же отвечает на него: «Ты не терпишь ущерба, если приобретаешь... вместо монетки - правильный поступок, вместо пустословия - спокойствие... вместо сквернословия - совесть» (там же: 233). Приговор не понимающим этого суров. Тот, кто не понимает этого, тот «труп» («мертвая душа», или «живой в гробу», если использовать современные определения). «А если бы он был чем-то болыше, то осознавал бы, что человек не бывает несчастным из-за другого человека» (там же: 57).

Но вера во внутренние творческие возможности человека не приводит Эпиктета к индивидуализму и самозамкнутости индивида. Аля самотворчества требуется помощь богов и добродетельных людей. «Затем, когда у тебя возникает какое-нибудь такое представление... обратись с мольбой к святилищам богов, отвращающих бедствия, достаточно даже, если ты, удалившись к общению с добродетельными людьми, предашься этому» (там же: 131). (Сравни со значением молитвы и общения с духовником в христианстве.) Кстати, Сенека в противоположность этому писал: «Что нужды в молитвах? Сделай сам себя счастливым» (Сенека, 1977: 58).

Надо страшиться не смерти или изгнания (потери работы и т. п.), но самого страха, т. е. не впадать в то, что представляется злом. И если ты сможешь изгонять пред- 
ставления, приводящие к смятению, значит, ты не зря учился у Эпиктета. Эпиктет говорит, в чем заключаются правильные мнения: «...в том, чтобы человек, целыми днями приучая себя к этому, не испытывал привязанности ни к чему чужому, ни к другу, ни к месту, ни к гимнасиям и даже к своему телу, а памятовал о законе и имел его перед глазами. А что это за закон? Закон бога. Свое сохранять, на чужое не притязать, пользоваться тем, что дается, не жаждать того, что не дается, а когда отнимается чтото, отдавать легко и тут же, с благодарностью за все время пользования этим» (Беседы Эпиктета, 1997: 124). Не испытывай привязанности к чужому, и ты не будешь желать этого и переживать из-за потери этого. «Очисть мнения: не пристало ли к тебе что-нибудь не-твое, не приросло ли, не причинит ли тебе мучений, если будет отрываться от тебя?» (там же: 226). Этими духовными упражнениями нужно заниматься каждый день, как тренируют свое тело гимнасты.

Здесь проявляются еще две особенности философии Эпиктета. Подчеркивая важность обращения к внутренним силам в человеке, римский стоик одновременно принижает все внешнее, что окружает индивида, в том числе его телесность, и называя это чужим, видит проявление свободы человека в непривязанности к внешнему и отказе желать его. «Имущество - это не мое. Родные, домашние, друзья, добрая слава, привычные места, времяпрепровождение - все это чужое» (там же: 206). Аанное перечисление показывает, что подавляющее большинство вещей - чужие для нас, и, стало быть, все представления, связанные с ними, не имеют к нам отношения, т. е. должны быть исключены из сферы нашего внимания. «А дело добродетельного человека - пользоваться представлениями в соответствии с природой. По природе же всякая душа рождена как признавать истинное, отвергать ложное, воздерживаться от суждения при неясном, так и по отношению к благу быть движимой к стремлению, по отношению к злу - избеганием, а по отношению к тому, что не зло и не благо, - ни тем, ни другим» (там же: 159). Такая природа души соответствует природе целого, и, стало быть, к этому должен стремиться каждый человек. Принцип Эпиктета: «свое блюди всячески, чужого не домогайся» (там же: 80).

То, что не в моей полной власти, - не мое. Сюда относятся имущество, собственные тело, жизнь, как и жизнь близких. Поэтому не стоит из-за всего этого волноваться, сохраняя спокойствие. Поняв и приняв әто, надо, вместо того чтобы переживать из-за не принадлежащего тебе, обдумывать собственные мысли и поступки, в которых мы всецело вольны. Вот мысль Эпиктета, которую легче понять, чем следовать ей на практике. Но это возможно, если подчинить свою волю воле бога, тогда как мой разум и моя воля зависят только от меня самого.

Возникает вопрос: не слишком ли много Эпиктет советует считать чужим? Что же нам, не думать о родных, друзьях, имуществе и многом другом? На наш взгляд, несомненная полемическая заостренность тезиса Эпиктета не дает оснований обвинить его в эскапизме. Римский стоик заботится о сохранении устойчивости внутреннего мира человека в ситуациях, когда приходят негативные представления, которые и надо отвергать. Если же они позитивные, то ничего не мешает нам допускать их и позволять располагаться в нашем сознании. Например, если произошло что-то хорошее вокруг нас, то радость по этому поводу (в пределах меры) вполне оправданна, так как радость относится к благим страстям.

А что же является для человека своим? Время, данное ему; добродетель, к которой он должен стремиться; собственные представления, которыми он должен управлять; собственные поступки, за которыми он должен следить. Бог дал человеку что-то, при- 
надлежащее ему, чтобы он был счастлив и стоек, а он досадует на бога за то, что тот сделал многое чужим для него. Но если человек будет испытывать привязанность к чужому, он понесет заслуженное наказание, как тот, кто домогается не принадлежащего ему. Причина нашего стремления к чужому - эгоизм и чувство собственности.

Из того, что подавляющее большинство вещей вокруг нас, чужие нам, следует необходимость отказа от привязанности к миру. «Стало быть, кто отказывается от притязаний на то, что относится к внешнему миру, тот достигает блага» (там же: 160). Чужое способно завладеть нашим сознанием и подчинить себе, как слова услышанной песни могут преследовать нас всегда и повсюду. «Почему же мы негодуем? Потому что мы дорожим предметами, которых нас лишают. Право же, не дорожи своими плащами, и не будешь негодовать на вора. Не дорожи красотой жены, и не будешь негодовать на прелюбодея. Знай, что вору и прелюбодею нет места в том, что твое, а лишь в том, что чужое и что не зависит от тебя» (там же: 71).

Что делать, когда какое-либо событие (чаще плохое) постоянно всплывает в памяти и никуда от него не деться, и ты накрепко привязан к нему? Стоики рекомендовали: 1) не привязываться ни к чему внешнему и стараться быть «легкоотвязываемым»; 2) менять представления на оптимистические и радостные; 3) культивировать в душе разумные намерения и благие деяния (милосердие, забота о близких в противовес эгоизму, жадности, гневу и т. п.); 4) больше думать о своем поведении и быть предусмотрительным, чтобы потом не раскаиваться (порой лучше недеяние, чем деяние). Это относится и к общению. «Так до тех пор, пока эти прекрасные мнения не укрепятся в вас и вы не приобретете определенного умения быть непоколебимыми, советую вам с осмотрительностью сходиться с профанами» (там же: 180). Общаться, согласно Эпиктету, следует только с поступающими правильно.

Аревнее изречение «все свое ношу с собой» можно понимать и в том смысле, что вне меня нет ничего, что я могу считать своим. Эпиктет добавляет к этому: все мое неподвластно помехам и препятствиям. Из владения совестливости, честности, братолюбия изгнать человека не может даже бог.

Через разум и душу идет влияние и на тело - как в позитивном, так и в негативном смысле. Современные целители утверждают, что различные привязанности человека к объектам внешнего мира связаны с предрасположенностью к определенным заболеваниям. Из этого можно сделать вывод, что следование благу, как его понимают стоики, исцеляет человека и способствует сохранению его здоровья.

С дилеммой «свое - чужое» тесно связан вопрос о свободе воли. Последняя в основном распространяется только на принадлежащее нам. Философия научила меня, говорил Эпиктет, «видеть, что все происходящее, если не зависит от свободы воли, не имеет никакого отношения ко мне» (там же: 89). Наряду с осознанием пользы от нежелательных представлений и напрасности переживать из-за всего, что тебе не принадлежит, еще один способ, применяемый стоиками для того, чтобы избежать нежелательных представлений, представляет собой отказ от переживаний из-за всего, что находится вне компетенции нашей свободы воли. Человек должен внимательно рассматривать приходящие к нему представления на предмет их соотношения с его свободой воли.

Свобода воли распространяется на совокупность вещей, которые зависят только от нас и входят в сферу нашей добродетели. Противоположное понятие - безразличное. Это не благо и не зло. Можно сказать, что это все то, что не в нашей власти, внешнее нам. Из-за безразличного вообще не стоит волноваться. Эпиктет советовал отст- 
раняться от всего чужого, которое не зависит от свободы воли человека, в чем индивид не властен. «Один только путь к благоденствию... отказаться от всего, независящего от свободы воли, ничего этого не считать своим, предоставить все божеству, судьбе» (там же: 238). Например, не стоит переживать из-за поражения любимой команды, потому что результат матча никоим образом не зависит от тебя. Таким образом, из совокупности представлений удаляется очень многое, способное доставить негативную реакцию индивиду. Нас обидели, что может произойти в любой момент, но если мы не давали никакого повода, то не стоит из-за этого переживать. Наша совесть чиста, а мучиться должен тот, кто оскорбил нас.

Эпиктет советует в качестве духовного упражнения исследовать все, что видишь, и если это не зависит от свободы воли, то отбрасывать его прочь. «Так вот, следует искоренять в себе эти негодные мнения, в этом напрягать все свои усилия. Ведь что такое плач и стенанье? Мнение. Что такое несчастье? Мнение. <...> Пусть человек перенесет их на зависящее от свободы воли, и я ручаюсь ему, что он будет стоек, как бы у него ни обстояло все» (там же: 161). Свобода воли, стало быть, заключается в правильном пользовании представлениями. Это - сущность блага, по Эпиктету. Боги «дали тебе не быть ответственным за родителей, и за братьев, и за тело, имущество, смерть, жизнь» (там же: 64). «Так ответственным за что сделали они тебя? Только за то, что зависит от тебя, - за пользование, как должно, представлениями» (там же).

От того, правильно ли люди понимают свободу воли, должно зависеть и отношение к ним. Эпиктет советовал справляться «о том, где они полагают пользу для себя, вовне ли или в свободе воли» (там же: 143). «Если вовне, то не называй их друзьями, точно так же, как и честными или твердыми, или смело уверенными, или свободными, но даже и людьми, если ты умен» (там же).

Установка не обращать внимания на то, что не входит в сферу свободы воли, помогает человеку стать свободным. «Ведь свобода обретается не исполнением того, чего жаждут, но подавлением жажды» (там же: 232). Это положение противоречит рекомендациям современных психологов, но совпадает с тем, что проповедовал полемизирующий со стоиками Эпикур. «Проведи ночи в трудах ради того, чтобы добиться мнения, делающего свободным <...> Во всяком случае, попытайся хоть: попытка не постыдна» (там же). Правильные мнения о зависимом и независимом от нас «делают людей свободными, неподвластными помехам, поднимают голову униженных, позволяют прямо смотреть в лицо богачам, в лицо тиранам» (там же: 215). Это и есть дар правильного представления и поступка. Итак, главный вывод Эпиктета и важнейшее, чему он учил в своей школе, заключается в том, что наивысшая победа человека - это победа над собой, и достигается она управлением собственными умственными представлениями.

\section{ЗАКАЮЧЕНИЕ}

Эпиктет вобрал в себя многое из предшествующей мудрости человечества. Читать книги, полагал он, надо для того, чтобы выучиться правильно жить. Мы видим у Эпиктета буддистские нотки, но Будда говорил о полном освобождении от желаний, а Эпиктет - об освобождении от чрезмерной привязанности. Желать же надо «только того, что в нашей власти, того, что возможно» (Эпиктет, 1995b: 217). В этом случае мы также освободимся от страданий. Близок Эпиктет и к пониманию кармы и индусов, утверждая, что «нельзя сделать ни одной несправедливости безнаказанно» (там же: 239). В решении дилеммы, что лучше: совершить несправедливость или претерпеть 
ее, - Эпиктет на стороне Сократа: «А из двух людей - кто победитель; тот ли, который мучит и убивает другого, или тот, кто терпеливо и не сердясь переносит свои мучения и смерть?» (там же: 240). Есть общее в отношении к Богу у Эпиктета и христиан (а также и мусульман, для которых покорность Богу является основополагающей).

Та свобода выбора, которую превозносит Эпиктет, напоминает концепцию этического выбора С. Кьеркегора и, таким образом, связывает стоицизм с экзистенциализмом. Это свидетельствует о том, что стоические идеи в иной форме дошли до современной философии. Следуя римскому философу, мы можем отвергать подавляющее большинство приходящих к нам негативных представлений, говоря им: «Это не мое», а некоторые из них переоценивать позитивно как соответствующие закону целого, которому мы должны подчиняться, или помогающие нам совершенствоваться. На основании принципов Эпиктета негативные представления можно превращать в позитивные, рассматривая их как: 1) потребные нам в качестве духовных упражнений или как помощь в самосовершенствовании; 2) благо для целого, частичкой которого мы являемся и которому мы должны служить; 3) посылаемые богом для нашего блага, во что мы должны верить. Негативные представления можно также ментально устранять как относящиеся: 4) к чужому и безразличному для нас; 5) к тому, что находится вне компетенции нашей свободы воли.

В своих методах работы с представлениями Эпиктет использовал то, что на современном научном языке называется гиперстимуляцией и гипостимуляцией. Он рекомендовал прекратить заботу об очень многом, что на поверку оказывается чужим, но зато остальное (в пределах свободы воли) исполнять сурово и неукоснительно. Вся философия эпикурейцев и стоиков - «только путь освобождения от печальных последствий их мрачного Аушевного состояния» (Ажемс, 1992: 123). Можно сказать и так: путь достижения и сохранения позитивного настроя. Мрачное душевное состояние - удел не только ушедших в прошлое эпикурейцев и стоиков.

Остались в прошлом эти направления античной философии. Но в любом социуме часто бывают обстоятельства, которые грозят лишить индивида покоя, самообладания и здоровья. В наше время большая часть народонаселения Земли страдает от психосоматических заболеваний, и врачи бьют тревогу по этому поводу. В этих условиях воззрения философов, и в том числе практические методы Эпиктета, выработанные и примененные им в его школе, оказываются весьма кстати и требуют изучения и дальнейшего развития. Современная медицина предупреждает об опасности самолечения. Но самотворчество, основанное на серьезном изучении проверенных веками философских рецептов, необходимо для человека.

\section{СПИСОК АИТЕРАТУРЫ}

Адо, П. (2005) Античная философия как духовное упражнение. М. ; СПб. : Степной ветер ; ИА «Коло». 448 с.

Бердяев, Н. А. (1989) Смысл творчества // Философия свободы. Смысл творчества. М. : Правда. 607 с. С. 254-534.

Бердяев, Н. А. (1993) О назначении человека. М. : Республика. 383 с.

Беседы Эпиктета (1997) / подг. Г. А. Таронян. М. : Аадомир. 412 с.

Ажемс, В. (1992) Многообразие религиозного опыта. Репр. иза. СПб. : Андреев и сыновья. 418 с.

Маковельский, А. (1912) Мораль Эпиктета. Казань : Типо-лит. Имп. ун-та. 37 с.

Митрополит Иерофей (Влахос) (2013) Православная психотерапия. Сергиев Посад : ИзА-во Свято-Троицкой Сергиевой Аавры. 368 с. 
Сенека (1977) Нравственные письма к Ауцилию / изд. подгот. С. А. Ошеров. М. : Наука. 383 с.

Флавий Арриан (2007) Руководство Эпиктета // Мемнон. Исследования и публикации по истории античного мира / пер. с древнегреч. А. Я. Тыжова ; под ред. Э. А. Фролова. СПб. : Изд-во СПб. гос. ун-та. Вып. 6.680 с. С. 515-532.

Эпиктет (1995а) Афоризмы // Римские стоики: Сенека. Эпиктет. Марк Аврелий : сб. М. : Республика. 463 с. С. 252-271.

Эпиктет (1995b) В чем наше благо? // Римские стоики: Сенека. Эпиктет. Марк Аврелий : сб. М. : Республика. 463 с. С. 206-251.

Аата поступления: 12.05.2018 2.

\section{SELF-CREATION AND PRINCIPLES OF WORK WITH INSIGHTS \\ IN EPICTETUS'S SCHOOL}

A. A. GORELOV

RAS INSTITUTE OF PHILOSOPHY

The article discusses the importance of working with insights in Epictetus's school for human development. The first part of the article analyses the concept of self-creation in its correlation with the concept of creativity. Three meanings of the self-creation concept are analysed: the unconscious influence of creativity on the creator themself, the conscious influence of culture on the author's own being and the conscious impact on the creator themself as a goal in itself. Insights management is considered to be an important stage of self-creation, leading to further changes in behavior and lifestyle.

The article considers comprehending and non-comprehending, true and false insights; the dilemma of "my own - somebody else's", to which Epictetus gives fundamental significance; the concept of free will that the Roman stoic only applies to what is somebody's own. The principles used by Epictetus are analysed: 1) "comprehend" insights in accordance with God's instructions, great philosophers' behaviour, the interests of the whole and your own goals of self-improvement corresponding to nature; 2) "look after what is yours in every possible way, do not seek someone else's"; 3 ) get away from everything that does not depend on your free will. The analogies are drawn between Buddhist liberation from desire and Epictetus's liberation from affective fixation on external reality; the freedom of choice, about which Epictetus writes, and existentialist concept of ethical choice.

Despite the fact that stoicism is now not a fashionable philosophical school, the principles formulated by Epictetus are reproduced in modern philosophical and psychological literature. For example, the principle of non-attachment to the external material reality, the principle of hyperstimulation and hypostimulation, which are used to achieve altered states of consciousness and the like, go back to the teaching of Epictetus. Today, the views of the Stoics, and of Epictetus in particular, are as relevant as they were in antiquity.

Keywords: self-creation; Epictetus; Socrates; Diogenes; the Stoics; comprehending insight; my own - somebody else's; indifferent; free will; philosophy of creativity

\section{REFERENCES}

Ado, P. (2005) Antichnaia filosofiia kak dukbovnoe uprazhnenie. Moscow, St. Petersburg, Stepnoi veter; ID «Kolo». 448 p. (In Russ.).

Berdiaev, N. A. (1989) Smysl tvorchestva. In: Filosofiia svobody. Smysl tvorchestva. Moscow, Pravda. 607 p. Pp. 254-534. (In Russ.).

Berdiaev, N. A. (1993) O naznachenii cheloveka. Moscow, Respublika. 383 p. (In Russ.).

Besedy Epikteta (1997) / prep. by G. A. Taronian. Moscow, Ladomir. 412 p. (In Russ.).

Dzhems, V. (1992) Mnogoobrazie religioznogo opyta. Repr. izd. St. Petersburg, Andreev i synov'ia Publ. 418 p. (In Russ.).

Makovel'skii, A. (1912) Moral' Epikteta. Kazan', Tipo-lit. Imp. un-ta. 37 p. (In Russ.).

Mitropolit Ierofei (Vlakhos) (2013) Pravoslavnaia psikboterapiia. Sergiev Posad, Izd-vo SviatoTroitskoi Sergievoi Lavry. 368 p. (In Russ.). 
Seneka (1977) Nravstvennye pis'ma k Lutsiliiu / prep. by S. A. Osherov. Moscow, Nauka. 383 p. (In Russ.).

Flavii Arrian (2007) Rukovodstvo Epikteta. In: Memnon. Issledovaniia i publikatsii po istorii antichnogo mira : transl. by A. Ia. Tyzhov; ed. by E. D. Frolov. St. Petersburg, Izd-vo SPb. gos. un-ta. Vol. 6. 680 p. Pp. 515-532. (In Russ.).

Epiktet (1995a) Aforizmy. In: Rimskie stoiki: Seneka. Epiktet. Mark Avrelii : collection. Moscow, Respublika. 463 p. Pp. 252-271. (In Russ.).

Epiktet (1995b) V chem nashe blago? In: Rimskie stoiki: Seneka. Epiktet. Mark Avrelii : collection. Moscow, Respublika. 463 p. Pp. 206-251. (In Russ.).

Submission date: 12.05 .2018 .

Горелов Анатолий Алексеевич - доктор философских наук, ведущий научный сотрудник Института философии РАН. Адрес: 119842, Россия, г. Москва, ул. Гончарная, А. 12. Тел.: +7 (495) 697-91-28. Эл. aspec: evolepis@iph.ras.ru

Gorelov Anatoliy Alekseyevich, Doctor of Philosophy, Leading Research Fellow, RAS Institute of Philosophy. Postal address: 12, Goncharnaya St., Moscow, Russian Federation, 119842. Tel.: +7 (495)697-91-28. E-mail: evolepis@iph.ras.ru 